\title{
SIMULATION AND GAMIFICATION IN E-LEARNING TECHNICAL COURSES
}

\author{
Ghiță BÂRSAN*, Vasile NĂSTĂSESCU**, Vlad-Andrei BÂRSAN*** \\ * "Nicolae Bălcescu" Land Forces Academy, Sibiu, Romania \\ ** Military Technical Academy, Sibiu, Romania \\ *** "Lucian Blaga" University, Sibiu, Romania \\ ghbarsan@gmail.com
}

\begin{abstract}
The paper is based on the experience gained in creating eLearning courses to keep the student's interest high, to encourage them to study additional materials in order to achieve the level of complexity proposed by the discipline objectives. The combination of specific gaming-techniques with simulation elements has been combined into designing the e-learning content. The degree of motivation and the interest in the discipline were appreciated by comparing the results obtained by students attending a blending-learning to those students who did the didactic activities in the traditional way. At present, there is a decrease in students' interest in technical subjects. On one hand, the complexity of these disciplines is high, and moreover, in order for the students to achieve the didactic objectives of the discipline, they must make a sustained effort and combine the individual study with the explanations in the classroom.
\end{abstract}

Keywords: motivation for learning, interaction, simulation, gamification

\section{Introduction}

The current development directions applied in the design of content online refer to concepts such as m-Learning, microlearning, mobile apps for learning as well as gamification, simulation and interactivity [1].

The synergy between the trend and the coherence of the teaching objectives can lead to measurable results both in long-life learning and in student - centered learning in the training phase. m-Learning, microlearning and mobile apps for learning refer to the device independence, welldesigned responsive contents, and lessons consisting of modules that require a short time for scrolling [2].

If these concepts are more suited to longlife-learning, interactivity and simulation can also be used in blended learning for undergraduate programs of study [3]. The degree of interactivity in the content or the assessment part is designed to maintain a high level of interest for the student. In the content creation section, explanations combined with simulation or asynchronous interactions allow students to understand the phenomena at their own pace and resume them whenever they feel the need [4]. Simulation and interactivity integrated in assessment tests allow for both the learning level and directing towards sections that may be less understood, as well as learning from mistakes. Whether the course takes place in the traditional space, or it is blending, or is entirely in the virtual space, the role of the teacher is very important and the combination of the traditional pedagogical techniques and the advantages of using the computer can be demanding. But if the goals are achieved by most of the class participants, and the 
students can get a high degree of abstraction, then, no effort made by the teacher is considered too high. In order to maintain the students' interest, the development focuses on contents that bring elements of virtual reality, game-based learning, interactivity, simulation, or gamification.

Game-based learning in higher education involves the use of video games in order to train students ready for teamwork and for solving limit-situations and communication [5].

Interactivity and simulation assures a permanent dialogue between learners and eLearning content and can bring the student closer to a real experience. Interaction and simulation can be introduced by using Authoring tools or by integrating e-learning objects developed in programming environments. If, initially, the content was static, based on .doc or .ppt files, nowadays the need for a participative engagement of the student in the lesson can only be achieved through interactivity [6].

Gamification involves the use of gamingspecific mechanisms and rules in the learning process. Gamification, viewed as a set of strategies, tactics or learning products, can reshape the eLearning environment if the content is designed to meet clearly defined objectives in agreement with the target group to which it is intended [7].

Designing e-learning contents by using topical elements can keep students' interest in a discipline [8]. However, regardless of the methods approached, the learning objects must be designed in accordance with specific teaching objectives. [9] Starting from the necessity of integrating the elements of gamification and simulation into the e-Learning contents for the Strength of materials discipline, respectively the Artillery Barrels Autofretting course [10], we intend, on one hand, to create learning objects that keep the students' interest and, on the other hand, the student understands the differences between the types of auto-fretting processes with emphasis on the hydrostatic process [11], and the diagram characteristic to the material [12], [13], - elements studied within the Strength of materials subject.

\section{Creating e-Learning contents}

The learning objects that are in line with the new trends in the field and awaken the learner's motivation for learning, can be created either by using Authoring tools or by designing Java or $\mathrm{C}++$ applets that afterwards comply with the SCORM standard [14].

The theoretical aspects combined with gaming-specific elements in the educational content and interaction or simulation can encourage, support and facilitate the learning process [15]. The gamification strategies as well as the customizing content for each student, the setting of rules and ramifications, reviewing the ambiguous parts are just a few aspects that need to be considered in the design of the learning content, regardless of the tool that is used [16].

The adoption of gaming-specific rules accompanied by simulation is mainly used for the laboratory works when the provision of technical rooms requires a sustained financial effort or the development of certain skills for students is more than necessary.

\subsection{E-Learning object based on gamification}

In designing courses with technical content, respectively of those of the Strength of Materials, we started from an engaging scenario simulating reality, and additionally, the students had to observe certain rules: during the explanations one cannot intervene, the time associated with each question is set depending on the degree of difficulty, the failure to end in the given time means wrong answer and the return to the associated explanation part, the lesson does not have a linear path, it is individualized according to the selected option or the given answers.

The elements of mystery and curiosity [7] 
were introduced in order to draw the students' attention and to raise their interest in additional materials in order to ensure a high degree of complexity. The short theoretical sequences have always been followed by simple questions to generate decision situations so that the student can gain confidence in his or her own forces and make him/her continue to study, and last but not least, to achieve didactic goals. The complexity was introduced gradually, using simulation elements [17].

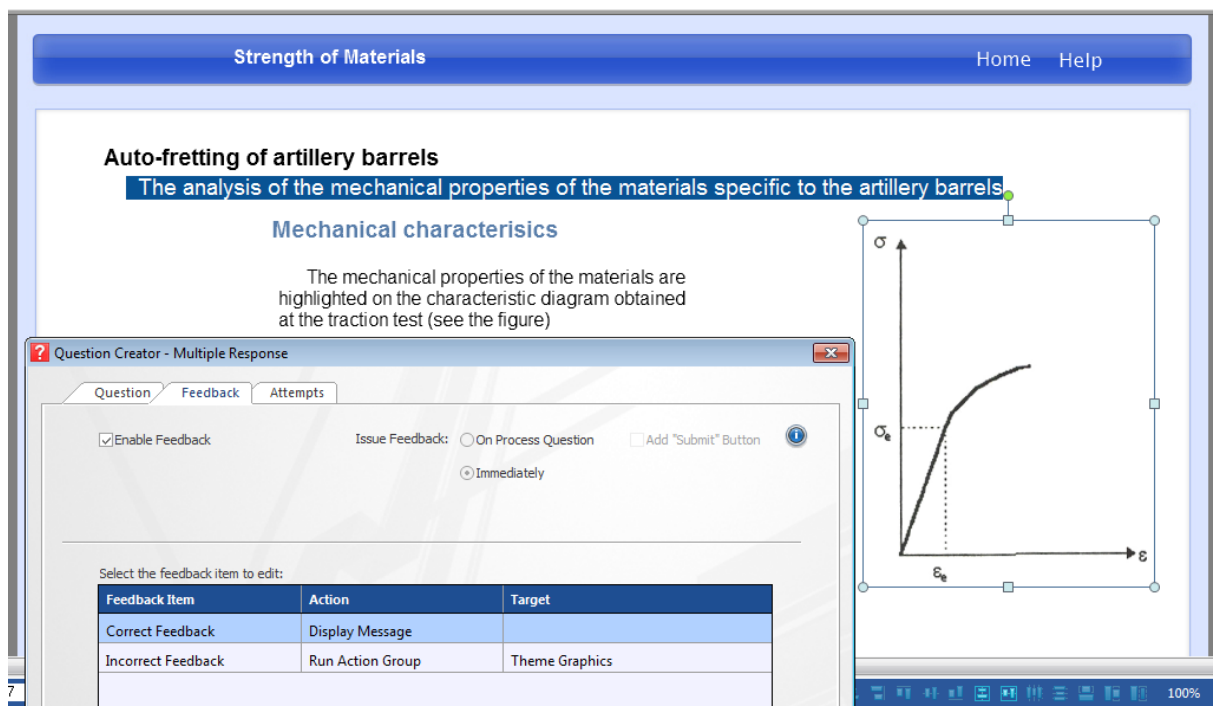

Figure 1. Defined scenario for understanding the hydrostatic process [3]

After generating lessons in Authoring tools Lectora, the files were packaged in SCORM and imported to the eFront platform of the institution, from where to be accessed by those having an account and password.

\section{The impact analysis}

For the impact analysis, during the seminar classes, the students attending the course were divided into 2 groups:

- the first group - G1 - had traditional seminar activities in the classroom, receiving and discussing the debated aspects face-to-face;

- for the second group - G2 - a blended learning was applied, the course was traditionally held in the classroom, and the seminar classes took place on the eLearning platform.

The group breakdown was random based on the seminar groups. From the point of view of the environmental, technological and pedagogical variables, the groups were relatively homogeneous, that is, the seminars for all those who were distributed on the platform were held on the same computers and the same type of Internet connection. The teacher applied the same didactic strategies both at the course and at the seminar. The differences at the level of each group are related to the concentration capacity and the knowledge of each student [18].

After the seminar classes allotted to assignments all students were evaluated on the platform through a common test consisting of multiple choice, matching and short answer questions [9]. During the final stage, a complex questionnaire with 30 items was designed and applied to each group to measure the quality of the program, the educational resources and the level of ICT. The data we obtained were statistically processed and the results of our study confirm that e-learning enables the introduction of the new formula in teaching mechanical engineering courses based on asynchronous e-content by providing extra information or additional learning methods besides the traditional courses.

Using the available LMS reports, Lesson Reports, we analyzed how students responded to each question. We were not 
interested in the score obtained by each group, but sought to consider whether there were differences in motivation and interest in this course. Three-level scales have been used to indicate the level of their agreement or disagreement:

- the first scale: 1=strongly agree, $2=$ agree, $\quad 3=$ neutral, $\quad 4=$ disagree, $5=$ strongly disagree;

- the second scale: $1=$ very often, $2=$ often, $3=$ occasionally, $4=$ rarely, $5=$ never;

- the third scale: 1=excellent, 2=good, $3=$ average, $4=$ poor, $5=$ ineffective.

Regarding the use of the specific language, the first group (G1) did better with the new terms and concepts, while the students in G2 group understood the presented phenomena better and were able to make the connections easier.

Based on the Lesson Report available on the platform, it was noted that most of the students (G2) were more interested in the course, studied the platform after the seminar hours, resumed the materials presented and tried to solve the additional optional tasks proposed for both groups an aspect highlighted by solving the corresponding test questions.

As an example, in figure 2 the differences between the two groups' assessments regarding the evaluation of the didactic strategy used are highlighted.

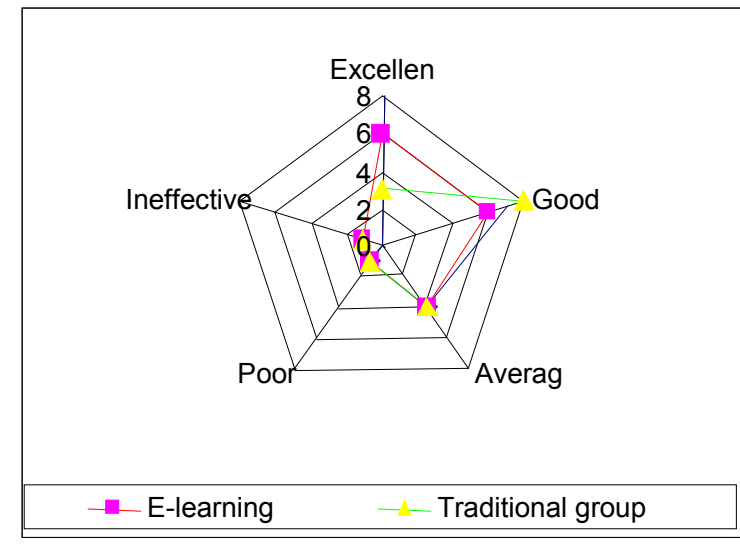

Figure 2 Overall results

The results for the two groups are similar, but this does not entitle us to jump to conclusions and say that traditional learning can be replaced by forms of advanced distributed learning.

At the same time, the results obtained by testing the G1 group for questions related to facultative tasks were much weaker, which could be an indicator of group motivation.

\section{Conclusions}

By adopting blended leaning for undergraduate studies, we can maintain a high interest in the subjects studied by students. The integration of new concepts gamification, simulation, or interactivity into the elearning content allows for a differentiated course for each student according to his/her level of knowledge and facilitates the explanation of phenomena, processes that, in the traditional education, require a great financial effort. Moreover, if there is interest and motivation on behalf of the student, by combining simulations with gamification, students can achieve the learning objectives set for each discipline.

\section{References}

[1] Pandey A., eLearning Trends And Predictions For 2017, in eLearning Industry, 2017 available at: https://elearningindustry.com/elearning-trends-and-predictions-2017;

[2] Giurgiu L., Microlearning - an envolving elearning trend, in Land Forces Academy Scientific bulletin, vol 22 issue 1, 2017 (in press);

[3] Bârsan G., Giurgiu L., Bumbuc S., E-content si web pedagogie în domeniul teoriei curgerii plastice, Ed. Academiei Forţelor Terestre, Sibiu, 2008, ISBN 978-973-153048-2; 
[4] Oancea R., Gligorea I., eLearning - soluţie modernă de învăţare şi testare a cunoştinţelor de legislaţie rutieră, în Arma Auto - 100 de ani de existenţă, continuitate şi perspective, Ed. Academiei Forţelor Terestre, Sibiu, pp.139-154, 2017;

[5] McClarty K.L., Orr A., Frey P.M., Dolan R.P., Vassileva V., McVay A., A literature review of gaming in education. Research report, Gaming in education, 2012;

[6] Paris M., Simulation authoring tools for interactive e-learning courseware development, Higher Education Academy Resources database, 2003, available at: http://uir.ulster.ac.uk/29184/1/id451_simulation_authoring_tools.pdf;

[7] Kapp K.M., The gamification of learning and instruction: game-based methods and strategies for training and education, John Wiley \& Sons, 2012;

[8] Bârsan G., Sfarlog B., Giurgiu L., et al., Implementing E-Content in the Field of Mechanical Engineering - a Lesson Learned, 5th Balkan Regional Conference on Engineering and Business Education \& ICEBE, "Lucian Blaga" Univ of Sibiu, Vols I and II, Conference Proceedings, pp 502-505, 2009;

[9] Giurgiu L., Bârsan G., Moşteanu D., E-Assessment's Role in the e-Learning Experience, 5th Balkan Region Conference on Engineering and Business Education/2nd International Conference on Engineering and Business Education, "Lucian Blaga" Univ, Sibiu, Romania, vols I and II, Conference Proceedings, pp. 75-79, 2009;

[10] Bârsan G., Bechet P., Barbu M., A Basic Theoretical Mode for Elastic-Plastic Stress Analysis of the Thick-Walled Tubes Subjected to an Internal Pressure, International Conference on Military Technologies (ICMP 2007), University of Defence, Military Technology Faculty, Brno, Czech Republic, pp. 65-70, 2007;

[11] Bârsan G., Giurgiu L., Implementing an e-Learning Solution for the Autofrettage of Thick Walled Tubes, 17th International Conference the Knowledge-Based Organization: Applied Technical Sciences and Advanced Military Technologies, Sibiu, Romania, Conference Proceedings, volume 3, pp. 13-19, 2011;

[12] Năstăsescu V., Barbu C., Bârsan G., Upon the Influence of Characteristics Parameters and Material Model Constants in SPH Analysis, 16th International Conference The Knowledge-Based Organization: Applied Technical Sciences and Advanced Military Technologies, Conference Proceedings, volume 3, pp. 88-93, 2010;

[13] Năstăsescu V., Bârsan G., Upon Some Material Models Used in Numerical Analysis of the Terminal Ballistic Effects by SPH Method, in 20th International Conference The Knowledge-Based Organization: Applied Technical Sciences and Advanced Military Technologies, Conference Proceedings, Volume 3, Sibiu, Romania, pp. 183-188, 2013;

[14] Berking P., Choosing Authoring Tool, version 9.5.7 ADL Instructional Design Team, Advanced Distributed Learning (ADL) Initiative, 2016;

[15] Giurgiu L., Bârsan G., Moşteanu D., Educational Issues in Computer Based Assessment, 8th European Conference on e-Learning, University of Bari, Bari, Italy on 29-30 October 2009, pp. 228-235, ISBN 978-1-906638-52-8;

[16] Virca I., Oancea R., Gligorea I., Advantages to use Elearning Platform in the Field of Technical Systems, the 13th International Scientific Conference eLearning and Software for Education, Bucharest, vol. 1, pp. 121-124, doi: 10.12753/2066-026X-17-018, 2017;

[17] Bârsan G., Giurgiu L., Moşteanu D., e-Plasticity: an Asynchronous e-Learning Solution for Artillery Barrels Autofrettage Process, 8th European Conference on e-Learning, University of Bari, Bari, Italy on 29-30 October 2009, pp. 52-59, ISBN 978-1-90663852-8;

[18] Attwell G., Evaluating e-learning: A guide to the evaluation of e-learning, Evaluate Europe Handbook Series Vol. 2, 2006; 